\title{
URGENSI PENGUATAN PARTISIPASI MASYARAKAT LOKAL DALAM PENGEMBANGAN WISATA PERDESAAN
}

\author{
Budiman Mahmud Musthofa \\ Program Studi Pariwisata Universitas Indonesia \\ budiman_mm@yahoo.com
}

\begin{abstract}
ABSTRAK
Pariwisata merupakan sektor yang sedang berkembang baik dari sisi industrinya maupun dari sisi kajian akademik. Pariwisata tidak saja dilihat dari sisi ekonomi melainkan lintas disiplin keilmuan yang salah satunya adalah sosiologi pariwisata. Aktivitas wisata perdesaan erat kaitannya dengan masyarakat karena mempertemukan antara wisatawan dan masyarakat lokal dalam suatu interaksi sosial. Wisata perdesaan merupakan salah satu peluang bagi perkembangan desa dan perkembangan pariwisata nasional. Pengembangan wisata perdesaan sangat berkaitan dengan partisipasi masyarakat. Hal ini sebagaimana telah berlangsung di beberapa destinasi wisata perdesaan di Indonesia. Kajian ini mencoba untuk menganalisa strategi menumbuhkan partisipasi masyarakat lokal dalam pengembangan wisata perdesaan. Kajian ini dilakukan dengan pendekatan kualitatif melalui studi kasus destinasi wisata perdesaan. Hasil kajian menunjukkan bahwa partisipasi masyarakat berperan sangat penting dalam kesuksesan pengembangan wisata perdesaan. Partisipasi harus dibangun bersama dengan memunculkan inisiatif masyarakat. Pada saat yang sama proses partisipasi harus mampu menghasilkan local champions yang mampu menjadi tokoh penggerak perubahan di masyarakat. Proses membangun partisipasi masyarakat dalam konteks apapun membutuhkan dukungan dari pihak-pihak yang terlibat di dalamnya sehingga mempercepat keberhasilan suatu destinasi wisata perdesaan. Partisipasi masyarakat yang positif dan produktif akan mendukung keberhasilan wisata perdesaan yang berkelanjutan.
\end{abstract}

Kata kunci: Partisipasi Masyarakat, Local Champions, Pariwisata Berkelanjutan, Wisata Perdesaan

\begin{abstract}
Tourism is a growing sector both in terms of its industry and in terms of academic studies. Tourism is not only seen from the economic side, but across scientific disciplines, one of which is the sociology of tourism. Rural tourism activities are closely related to the community because they bring together tourists and local communities in a social interaction. Rural tourism is one of the opportunities for the development of villages and the development of national tourism. The development of rural tourism is closely related to community participation. This has happened in several rural tourism destinations in Indonesia. This study tries to analyze the strategy of growing participation of local communities in rural tourism development. This study was conducted with a qualitative approach through a case study of rural tourism destinations. The results of the study show that community participation plays a very important role in the success of rural tourism development. Participation must be built together with community initiatives. At the same time the participation process must be able to produce local champions who are able to become agent of change in the community. The process of building community participation in any context requires the support of the parties involved in it so as to accelerate the success of a rural tourism destination. Positive and productive community participation will support the success of sustainable rural tourism.
\end{abstract}

Keywords: Community Participation, Local Champions, Sustainable Tourism, Rural Tourism 


\section{PENDAHULUAN}

Otonomi daerah yang berkembang sejak tahun 1999 telah mendorong pembangunan berbagai sektor diberbagai daerah. Sampai saat ini, perjalanan panjang otonomi daerah telah menjalar hingga ke desa. Sejak disahkannya UU No 6 Tahun 2014 tentang Desa, terlihat perubahan besar pada semangat pembangunan desa, baik dari pemerintah maupun masyarakatnya. Sebelum UU ini lahir, desa cenderung dianggap sebagai obyek pembangunan kini masyarakat desa menjadi subyek pembangunan. UU ini menempatkan desa sebagai subyek pelaku pembangunan. Kini warga desa melalui struktur yang ada memiliki wewenang penuh menjalankan pembangunan desanya. Modalnya tidak main-main, selain asset dan potensi yang ada di desa juga ditambah dana desa yang jumlahnya tidak main-main. Paradigma ini disebut sebagai ‘desa membangun'1. Desa mendapatkan keleluasaan dengan beragam otoritas dan pada saat yang sama memperoleh bantuan baik secara pendanaan melalui adanya dana desa, kesempatan kemitraan dengan korporasi dan beragam bantuan lainnya. Otoritas ini berdampak pada tumbuh berkembangnya desa, bahkan desa mampu menjadi pusat ekonomi kehidupan masyarakatnya. Melalui pola desa membangun diharapkan masa depan kehidupan warga desa semakin baik dan desa menjadi kekuatan ekonomi masyarakatnya.

Kebijakan dan program desa membangun idealnya mengarah pada sinergi kerjasama pemerintah dan masyarakat yang lebih baik, sehingga desa dapat tumbuh dan berkembang sesuai potensi dan kesepakatan masyarakatnya. Saat ini masyarakat dan aparat desa mulai tertarik pada pengembangan wisata perdesaan. Industri pariwisata, destinasi wisata, wisatawan menjadi istilah yang sudah sangat dikenal oleh masyarakat desa. Pada tahun 2018, tercatat dari data Potensi Desa (Podes) terdapat 1.734 desa wisata. Berdasarkan catatan BPS, dari 1.734 desa wisata tersebut tersebar di masing-masing kepulauan, dimana Pulau Jawa - Bali menempati posisi paling tinggi dengan 857 desa wisata. Kemudian diikuti dengan Sumatera sebanyak 355 desa, Nusa Tenggara 189 desa, Kalimantan 117 desa. Selain itu, Pulau Sulawesi juga tercatat sebesar 119 desa wisata, Papua 74 desa wisata, dan Maluku sebanyak 23 desa wisata $^{2}$. Kini pariwisata di daerah perdesaan (rural tourism) berkembang dengan pesat di Indonesia.

Pariwisata perdesaan kini berkembang pesat. Masyarakat desa mampu menawarkan berbagai produk dan sumber daya lokal bukan saja keindahan alamnya, tetapi mereka juga mampu menawarkan pengalaman hidup di desa. Pengembangan wisata perdesaan merupakan peluang besar yang harus direncanakan agar bertahan lama sehingga memberikan kebermanfaatan yang

\footnotetext{
1 http://www.berdesa.com/beda-desa-membangun-dan-membangun-desa/, diakses tanggal 9 Januari 2020.

${ }^{2}$ https://www.merdeka.com/uang/data-bps-indonesia-miliki-1734-desa-wisata.html, diakses 9 Januari 2020
} 


\section{Budiman Mahmud Musthofa}

luas bagi masyarakat dan perkembangan pembangunan desa. Pada aspek inilah kajian sosiologi pariwisata dan sosiologi perdesaan memiliki peran penting dalam membangun wisata perdesaan. Bagaimana menumbuhkan partisipasi masyarakat dan membangun inisiatif lokal dalam pengembangan wisata perdesaan? Pertanyaan inilah yang hendak dijawab pada kajian ini melalui berbagai kajian dan studi kasus wisata perdesaan dan desa wisata di Saung Angklung Udjo yang berlokasi di Bandung Jawa Barat dan Desa Wisata Bejiharjo di Gunungkidul, Yogyakarta.

\section{METODE KAJIAN}

Kajian ini dilakukan dengan metode penelitian kualitatif. Penelitian kualitatif merupakan metode untuk mengeksplorasi dan memahami makna yang oleh sejumlah individu atau sekelompok orang dianggap berasal dari masalah sosial atau kemanusiaan (Creswell, 2010). Penelitian ini menggunakan teknik pengumpulan data studi pustaka, observasi dan wawancara kepada stakeholder di destinasi wisata Saung Angklung Udjo dan Desa Wisata Bejiharjo.

\section{KERANGKA KONSEP}

Pariwisata adalah fenomena kemasyarakatan, yang menyangkut manusia, masyarakat, kelompok, organiasi, kebudayaan dan sebagainya yang merupakan obyek kajian sosiologi. Sosiologi pariwisata adalah kajian tentang kepariwisataan dengan menggunakan perspektif sosiologi, yaitu penerapan prinsip, konsep, hukum, paradigm dan metode sosiologis di dalam mengkaji masyarakat dan fenomena pariwisata untuk selanjutnya berusaha mengembangkan abstraksi-abstraksi yang mengarah kepada pengembangan teori (Pitana, 2005). Pariwisata adalah berbagai macam kegiatan wisata dan didukung berbagai fasilitas serta layanan yang disediakan oleh masyarakat, pengusaha, Pemerintah, dan Pemerintah Daerah. Salah satu elemen penting dalam pariwisata adalah Daya Tarik Wisata (DTW). Daya Tarik Wisata (DTW) adalah segala sesuatu yang memiliki keunikan, keindahan, dan nilai yang berupa keanekaragaman kekayaan alam, budaya, dan hasil buatan manusia yang menjadi sasaran atau tujuan kunjungan wisatawan (UU No 10 tahun 2009).

Wisata perdesaan merupakan salah satu Daya Tarik Wisata. Pengembangan dan pemanfaatan daerah perdesaan menjadi daya tarik wisata yang berkembang pesat dikarenakan keinginan customer untuk menghabiskan liburan yang unik mencari pemandangan yang asli dan asri, ketenangan, kualitas lingkungan hidup yang baik serta perhatian secara personal yang ditawarkan masyarakat dan usaha kecil di desa, serta adanya dukungan pemerintah setempat dalam mendorong pembangunan kepariwisataan di daerah perdesaan (Long \& Lane, 2000). 
Wisata perdesaan terus berkembang dan secara istilah kemudian lebih popular dengan sebutan desa wisata. Kementerian Kebudayaan dan Pariwisata (2011) mendefinisikan desa wisata sebagai suatu bentuk integrasi antara atraksi, akomodasi dan fasilitas pendukung yang disajikan dalam suatu struktur kehidupan masyarakat yang menyatu dengan tata cara dan tradisi yang berlaku. Segala sumber daya yang ada di desa berada dalam satu tatanan atau sistem yang saling mendukung tujuan pariwisata. Pariwisata menjadi fokus atau tema utama pembangunan desa. Hal ini sejajar dengan fokus pembangunan desa lainnya seperti desa kerajinan, desa budaya, desa nelayan, desa industri, dan sejenisnya.

Wisata Perdesaan harus direncanakan secara baik sehingga mendukung dalam pengembangan kepariwisataan (Martin dan Tomas, 2012). Para pengambil kebijakan, pelaku industry pariwisata dan masyarakat perlu memikirkan suatu model pengembangan wisata perdesaan yang tepat sehingga sesuai dengan potensi desa, didukung oleh masyarakatnya dan dapat memiliki keunikan yang membedakan dengan dea-desa lainnya. Pengembangan destinasi secara teoritik dan praktik dapat dianalisa melalui kerangka pengembangan destinasi pariwisata (Cooper, 1996; Sunaryo, 2013) sebagai berikut:

a) Obyek daya tarik wisata (Attraction) yang mencakup keunikan dan daya tarik.

b) Aksesibilitas (Accessibility) yang mencakup kemudahan sarana dan sistem transportasi.

c) Amenitas (Amenities) yang mencakup fasilitas penunjang dan pendukung wisata.

d) Fasilitas tambahan (Ancillary Service) yang mendukung kegiatan pariwisata.

e) Kelembagaan (Institutions) yang memiliki kewenangan, tanggung jawab dan peran dalam mendukung terlaksananya kegiatan pariwisata.

Partisipasi masyarakat lokal harus dilibatkan sejak awal rencana pengembangan wisata perdesaan. Secara teoritik, ada beberapa tipologi partisipasi masyarakat yang dikategorikan menjadi beberapa bentuk, yaitu partisipasi pasif, partisipasi pada pemberian informasi, partisipasi melalui konsultasi, partisipasi karena insentif materi, partisipasi fungsional, partisipasi interaktif, serta memobilisasi diri (Tosun, 2000; Kamarudin, 2013, Adi, 2013). Keterlibatan masyarakat dapat berupa partisipasi yang digerakan atas dasar kesadaran maupun paksaan (Sztompka, 2011). Partisipasi menjadi penting karena melalui budaya partisipasi suatu aktivitas kreatif yang berbasis pada budaya lokal akan semakin didukung oleh masyarakat sehingga memberikan dampak pada keberhasilan program. Keberhasilan program akan terjadi karena semua orang diberi kesempatan dan sarana untuk terlibat dalam proses partisipasi tersebut (Fischer, 2011; 2014). 
Masyarakat merupakan pihak yang paling langsung mendapatkan dampak. Karenanya, jika dampak positif diterima maka masyarakat akan semakin giat berpartisipasi. Pitana (2002) menyatakan bahwa untuk dapat meningkatkan partisipasi masyarakat maka sangat diperlukan program-program atau inovasi-inovasi yang dikembangkan mengandung unsurunsur:

1) Memberikan keuntungan secara relatif, terjangkau secara ekonomi dan secara ekonomis dianggap biaya yang dikeluarkan lebih kecil dari hasil yang diperoleh (relative advantage);

2) Unsur-unsur dari inovasi dianggap tidak bertentangan dengan nilai-nilai dan kepercayaan setempat (compatibility);

3) Gagasan dan praktek baru yang dikomunikasikan dapat dengan mudah dipahami dan dipraktekkan (complexity and practicability); dan

4) Unsur inovasi tersebut mudah diobservasi hasilnya lewat demontrasi atau praktek peragaan (observability).

\section{PEMBAHASAN}

\section{1) Pengembangan Destinasi Wisata Perdesaan}

Pengembangan wisata perdesaan lebih mudah dilakukan jika dibandingkan dengan mengembangan desa wisata. Pengembangan desa wisata lebih berat karena menekankan pada lokasi desa itu sendiri dengan aktivitas masyarakat dan keunikan desa yang dipadukan sebagai asset utama yang ditawarkan pada wisatawan. Desa wisata haruslah sebuah desa yang memiliki berbagai aspek yang mendukung desa itu untuk menjadi tujuan wisata yang menarik dengan segala daya dukungnya. Apabila ada sebuah desa yang hanya memiliki satu, dua atau sedikit obyek wisata dengan fasilitas seadanya maka tidak dapat disebut sebagai desa wisata. Sebuah desa, untuk menjadi desa wisata, maka pemerintah desa dan masyarakat harus mendukung secara penuh. Bukan hanya soal pendanaan dan pembiayaan, namun juga harus bisa meningkatkan partisipasi masyarakat dalam pengelolaan dan pembiayaan desa wisata tersebut.

Pengembangan desa wisata maupun wisata perdesaan memerlukan partisipasi dan dukungan berbagai stakeholder termasuk di dalamnya perlu ada pendampingan secara profesional dari ahli sehingga masyarakat dapat belajar dan membangun kapasitasnya untuk menuju kemandirian. Berikut ini adalah dua contoh destinasi wisata perdesaan yang kemudian berkembang menjadi desa wisata dan berhasil hingga saat ini, yaitu Saung Angklung Udjo dan Desa Wisata Bejiharjo.

Salah satu contoh wisata perdesaan berbasis seni budaya Sunda yang telah berkelanjutan adalah wisata Saung Angklung Udjo (SAU) di Bandung Jawa Barat. Saung Angklung Udjo 
(SAU) didirikan pada tahun 1966 oleh Udjo Ngalagena dan Istrinya pada awalnya berupa sanggar seni budaya yang kemudian berkembang menjadi destinasi wisata budaya dengan beragam atraksi dan memberikan pengalaman bagi wisatawan berupa suasana perdesaan dengan pohon bamboo dan dekorasi alami. Udjo Ngalagena merupakan tokoh utama (local champion) dibalik kesuksesan Saung Angklung Udjo, yang telah berkembang lebih dari setengah abad. Aktivitas yang di tawarkan di SAU antara lain produksi angklung, pelatihan angklung dan pertunjukan angklung yang disajikan dalam nuansa kehidupan masyarakat Sunda perdesaan tahun 1960-an, didukung oleh guest house, restoran, souvenir, workshop, dan beberapa fasilitas pendukung lainnya ${ }^{3}$. Rata-rata wisatawan yang mengunjungi SAU setiap tiap tahun kurang lebih 250.000 wisatawan. Keterlibatan masyarakat sekitar snagat tinggi sejak SAU berdiri hingga saat ini. Berdasarkan wawancara dengan direktur SAU, keterlibatan masyarakat dalam aktivitas SAU lebih dari 1.000 orang dan sebagian besarnya adalah warga sekitar. Meskipun kawasan sekitar SAU sudah menjadi perkotaan, namun suasana perdesaan masih dijaga dan menjadi kekhasan yang ditawarkan oleh pengelola ${ }^{4}$. Sejak tahun 2015, keberhasilan SAU telah sedang direplikasi di Kabupaten Bandung melalui program Cijaringao Ecoland yang merupakan kerjasama dengan pemerintah Provinsi Jawa Barat. Pada tahun 2019 pengembangan angklung seperti SAU juga dilakukan di Kabupaten Garut melalui kerjasama SAU dengan Pemerintah Provinsi Jawa Barat juga.

Ada sangat banyak desa wisata di Yogyakarta. Salah satu contoh destinasi desa wisata yang penulis kunjungi dan kaji adalah Desa Wisata Bejiharjo. Desa wisata ini terus berkembang dan memberikan banyak manfaat bagi masyarakat dan pembangunan desanya berkembang pesat. Desa wisata ini merupakan desa wisata berbasis ekologi. Desa wisata ini sering disingkat dengan nama Dewa Bejo yang berlokasi di Kecamatan Karangmojo, Kabupaten Gunungkidul, Provinsi Yogyakarta (DIY). ${ }^{5}$ Daya tarik utamanya adalah Goa Pindul. Goa Pindul merupakan goa berair yang cukup unik, memiliki panjang sekitar 350 meter dan lebar 5 meter, di dalamnya ada berbagai ornamen alami, aliran air jernih yang tenang. Masyarakat setempat berhasil mengubah sungai bawah tanah menjadi tempat wisata susur gua menggunakan ban dalam atau cave tubing. Desa Wisata Bejiharjo ini awalnya dirintis oleh masyarakat, salah satu pelopornya adalah Subagyo yang merintis pembukaan goa, mulai dari pembersihan, pendekatan kepada sesepuh desa, ritual, sampai pemberdayaan masyarakat setempat hingga akhirnya dibuka

\footnotetext{
${ }^{3}$ https://angklungudjo.com/, diakses tanggal 9 Januari 2020

${ }^{4}$ Musthofa, Budiman Mahmud. Pengembangan Budaya Menuju Kesejahteraan Budaya : Pelajaran Dari Pengembangan Masyarakat Di Saung Angklung Udjo, Bandung, Jawa Barat. Sosio Informa, [S.1.], v. 4, n. 3, jan. 2019. ISSN 2502-7913. Available at: <https:// ejournal.kemsos.go.id/index.php/Sosioinforma/article/view/1600/875>. Date accessed: 08 mar. 2019. doi:https://doi.org/10.33007/inf.v4i3.1600.

5 https://desawisatabejiharjo.net/ada-apa-dengan-dewa-bejo-goa-pindul/, diakses tanggal 9 Januari 2020
} 


\section{Budiman Mahmud Musthofa}

sebagai objek wisata. Kini jumlah pengunjung setiap tahun mencapai ratusan ribu dan pengelolaannya dilakukan oleh BUMDes.

Desa Beriharjo kini telah berubah dan berkembang baik, dari desa yang dulunya merupakan salah satu desa tertinggal, miskin dengan tingkat pengangguran yang cukup tinggi, namun kini masyarakat mempunyai penghasilan tetap. Masyarakat berhasil diberdayakan dan mampu melakukan partisipasi dalam mengembangan destinasi wisatanya. Desa Wisata Bejiharjo memperoleh penghargaan sebagai juara pertama desa wisata tingkat DIY dan nasional pada 2012. Kementerian Pariwisata memberi penghargaan 10 besar penerima Cipta Award kategori pelestarian lingkungan ${ }^{6}$. Penulis mewawancarai beberapa pengelola dan masyarakat sekitar dan mereka menyatakan bahwa secara ekonomi mereka sangat terangkat dengan keberadaan wisata ini dan secara signifikan mereka memperoleh banyak manfaat serta kondisi desa juga semakin baik, apalagi saat ini mulai diarahkan penguatan SDM pariwisata secara profesional.

\section{2) Pengembangan Partisipasi Masyarakat Lokal}

Dari contoh 2 buah kasus di atas, ada beberapa hal yang dapat dipedalam dan dikaji secara ilmiah yaitu tentang bagaimana pentingnya, bagaimana urgensinya kekuatan partisipasi masyarakat lokal dalam keberhasilan suatu destinasi wisata perdesaan. Keberhasilan pengembangan wisata perdesaan ini juga tidka dapat dipisahkan dari kekuatan tokoh, kekuatan local champions yang mampu menginisiasi program dan menggerakan masyarakat dalam pengembangan destinasinya. Pengembangan wisata perdesaan dapat dilakukan oleh banyak pihak, dapat diinisiasi oleh pemerintah, masyarakat maupun pihak-pihak terkait lainnya. Tidak ada pola yang baku, hanya saja peran pemerintah dan masyarakat pada akhirnya sangat menentukan kemajuan destiasi itu sendiri.

Dari kasus diatas dapat dianalisa beberapa hal terkait bagaimana mengembangan wisata perdesaan, langkah awalnya adalah pada inisiatif lokal individu atau segelintir orang yang melakukan indentifikasi potensi pengembangan destinasi, kemudian bergerak melakukan pengembangan destinasi dan ternyata pada perkembangannya memberikan dampak yang dampaknya dirasakan oleh masyarakat sehingga masyarakat terlibat dan berpartisipasi aktif mendukung pengembangan destinasi tersebut.

Secara konseptual fakta ini dapat diformulasikan sebagai langkah awal pengembangan destinasi yaitu identifikasi potensi. Pada proses identifikasi awal ini, di banyak desa ditemukan bahwa kesadaran masyarakat mengenai pengembangan wisata perdesaan sebagian masih terbatas, pada saat yang sama banyak ditemukan bahwa ide pengembangan wisata perdesaan hanya

${ }^{6}$ https://desawisatabejiharjo.net/sejarah/, diakses tanggal 9 Januari 2020

7 | SGSIOGLLBAL : Jurnal Pemikiran dan Penelitian Sasiologi, Vol. 4, No. I, Desember 2019 
berada pada tataran elit setempat, bukan aspirasi dari kebanyakan masyarakat. Sebagai bagian dari kekuatan pendorong perubahan, inisiatif lokal perlu digalakkan dan dikondisikan dengan berbagai pendekatan. Peran pemerintah disini dapat berfungsi sebagai katalisator dan pasilitator program pengembangan destinasi yang mendukung partisipasi masyarakat lokal.

Langkah selanjutnya setelah dilakukan identifikasi adalah membangun kesadaran kolektif masyarakat. Upaya yang dilakukan untuk membangun kesadaran masyarakat adalah melalui sosialisasi dan secara organisatoris dapat dibentuk kelompok sadar wisata untuk melakukan gerakan sadar wisata. Gerakan ini merupakan sebuah konsep yang mengembangkan partisipasi dan dukungan para pemangku kepentingan dalam mendorong iklim yang kondusif bagi tumbuh dan berkembangnya wisata di suatu wilayah. Selama ini, gerakan sadar wisata di sejumlah daerah diwujudkan dengan adanya kelompok sadar wisata (Pokdarwis). ${ }^{7}$ Sadar wisata bukan saja dimiliki oleh pokdarwis melainkan juga harus dimiliki oleh semua warga masyarakat sehingga proses pengembangan wisata perdesaan semakin mudah dijalankan. Setelah kesadaran terbangun diharapkan masyarakat bergerak untuk memulai langkah-langkah membangun pariwisata perdesaan dan tentunya dengan pendampingan baik dari pemerintah, institusi kampus, swasta (investor), NGO maupun mitra lainnya dan kerjasama seluruh stakebolder.

Selama proses mengembangkan destinasi, proses penguatan partisipasi masyarakat harus dilakukan terus menerus dan ini adalah proses yang tidak akan pernah berakhir. Secara umum ada tiga hal mendasar dalam pengembangan destinasi wisata yang harus dianalisa, yaitu atraksi, aksesibilitas dan amenitas, namun dapat ditambahkan 2 hal penting lainnya yaitu fasilitas tambahan (ancillary service) dan kelembagaan (Cooper, 1996; Sunaryo, 2013). Pada awal pengembangan wisata perdesaan perlu dilakukan kajian terkait obyek daya tarik wisata (attraction), aksesibilitas (accessibility, amenitas (amenities), fasilitas tambahan (ancillary service), dan kelembagaan (institutions). Kajian ini harus jelas sejak proses awal dan dapat dipahami oleh seluruh stakeholder sehingga pengembangannya akan terarah. Kajian awal terkait pengembangan wisata perdesaan ini akan memberikan gambaran tentang kekuatan dan kelemahan potensi desa, permasalahan, kesiapan desa untuk dikembangkan menjadi destinasi wisata perdesaan, kesiapan SDM dan solusi atas semua kendala dan permasalahan selama berlangsungnya pengembangan wisata desa.

Seiring berlangsungnya proses penguatan partisipasi maka akan terlihat potensi SDM lokal yang membantu menyiapkan lahirnya local champion di masyarakat. Kehadiran local champion

\footnotetext{
${ }^{7}$ https://travel.kompas.com/read/2017/10/17/153900727/apa-itu-pokdarwis-. diakses 22 April 2019 Penulis : Kontributor Malang, Andi Hartik
} 


\section{Budiman Mahmud Musthofa}

penting karena tokoh-tokoh inilah yang akan menjaid agen perubahan di masyarakat. Tokohtokoh inilah yang pada akhirnya mampu mengambil inisiatif perubahan dan mampu menggerakan masyarakat (self mobilization). Dalam kasus di atas, local champion Saung Angklung Udjo adalah Udjo Ngalagena, Desa Wisata Bejiharjo adalah Subagyo dan beberapa rekanrekannya. Sebagaimana telah dijelaskan pada bagian terdahulu, bentuk partisipasi masyarakat yang diharapkan pada awal membangun pariwisata perdesaan adalah pada tahapan adanya interaksi secara aktif sehingga mudah untuk mencapai tahap mampu memobilisasi dirinya (Tosun 2000; Kamarudin, 2013; Adi, 2013).

Perkembangan destinasi pariwisata perdesaan pada akhirnya mengarah pada bisnis. Pariwisata dalam konteks ini harus dipahami sebagai suatu bisnis yang menawarkan pengalaman dan kenangan, begitu juga dengan pariwisata perdesaan. Pengalaman yang ditawarkan kepada wisatawan akan menjadi kunci keberhasilan dari suatu destinasi, termasuk di dalamnya destinasi wisata perdesaan. Destinasi wisata perdesaan harus menawarkan berbagai atraksi dan produk pariwisata unggulan sehingga akan memberikan pengalaman yang tak terlupakan bagi wisatawan. Pada pengelolaan destinasi pertimbangan aspek pengalaman dan kenangan yang akan dirasakan oleh wisatawan harus sudah dipikirkan sejak tahap perencanaan pariwisata (Ritchie \& Crouch; 2003). Kekuatan dalam menawarkan pengalaman inilah yang akan menjadi keunggulan bagi sebuah destinasi dibandingkan destinasi yang lain. Pengalaman kemudian disampaikan dalam story-telling yang kemudian menjadi populer dan dapat dibagi ke masyarakat luas lainnya (Woodside, 2010). Pada konteks saat ini, story-telling bukan sebatas cerita dari mulut ke mulut, melainkan menjaid bagian penting yang mempromosikan wisata jika di sebarkan melalui sosial media seperti facebook, twitter, instagram dan berbagai platform lainnya.

Kekuatan sharing pengalaman dari wisatawan ternyata memberikan kontribusi besar peningkatan kunjungan wisatawan ke suatu destinasi wisata. Destinasi yang semakin berkembang ini diharapkan mampu mendukung pengembangan pariwisata desa yang berkelanjutan (Sustainable Tourism Development). Komponen pariwisata berkelanjutan merupakan turunan dari konsep pembangunan berkelanjutan. Pembangunan berkelanjutan merupakan suatu proses pembangunan yang berusaha untuk memenuhi kebutuhan sekarang dan selanjutnya diwariskan pada generasi mendatang (Gunawijaya, 2016). Melalui pembangunan pariwisata yang berkelanjutan ini diharapkan masyarakat desa dapat hidup dengan baik, pembangunan berjalan secara seimbang, lingkungan dapat terjaga dan secara ekonomi memperoleh manfaat yang mendukung kesejahteraan bersama. Akhir kata, partisipasi masyarakat yang positif menjadi memberikan dampak yang sangat besar dalam pengembangan destinasi wisata berkelanjutan. Partisipasi masyarakat menjadi komponen yang penting dan 
memiliki korelasi yang sangat kuat atas keberhasilan suatu pengembangan destinasi wisata di perdesaan.

\section{SIMPULAN}

Saat ini wisata perdesaan merupakan salah satu alternatif baru untuk meningkatkan kesejahteraan masyarakat perdesaan. Beragam potensi wisata yang dimiliki desa-desa di Indonesia perlu dikembangkan dalam konteks desa membangun baik melalui inisiatif dari dalam maupun inisiatif dari luar. Pengembangan destinasi wisata perdesaan akan berhasil jika direncanakan dengan baik dan melibatkan kerjasama dengan seluruh pihak-pihak yang berkepentingan. Proses pengembangan wisata perdesaan harus melibatkan partisipasi lokal karena kekuatan dari dalam ini mampu menggerakan masyarakat, memiliki daya tahan yang lebih kuat dibandingkan dengan dorongan yang lahir dari luar. Partisipasi masyakarat lokal perlu dimunculkan dan diperkuat melalui proses pendampingan yang professional hingga memunculkan local champion yang diharapkan mampu menjadi agen penggerak perubahan di masyarakatnya. Melalui upaya ini diharapkan upaya memperkuat partisipasi masyarakat lokal untuk mengembangkan wisata perdesaan dapat lebih optimal dan mampu mewujudkan wisata perdesaan yang berkelanjutan.

\section{DAFTAR PUSTAKA}

Adi, Isbandi Rukminto. (2013). Intervensi Komunitas \& Pengembangan Masyarakat Sebagai Upaya Pemberdayaan Masyarakat. Jakarta: PT Raja Grafindo Persada.

Cooper, C., Fletcher, J., Gilbert, D., \& Wanhill, S. (1996). Tourism Principle \& Practice. London: Longman Group Limited.

Creswell, J.W. (2010). Research Design Pendekatan Kualitatif, Kuantitatif, dan Mixed. Yogyakarta: Pustaka Pelajar

Fischer, G. (2014). "Learning, Social Creativity, and Cultures of Participation" in A. Sannino, \& V. Ellis (Eds.), Learning and Collective Creativity: Activity-Theoretical and Sociocultural Studies, Taylor \& Francis/Routledge, New York, NY, pp. 198-215. http://13d.cs.colorado.edu/ gerhard/papers/2013/helsinki.pdf.

Fischer, Gerhard and Frank Shipman (2011) , Collaborative Design Rationale And Social Creativity In Cultures Of Participation, Volume 7 (2), August 2011, An Interdisciplinary Journal on Humans in ICT Environments . ISSN: 1795-6889, University of Colorado, USA

Gunawijaya, Jajang, Dkk. (2016). Model Pengembangan Dan Kajian Destinasi Wisata Pedesaan Indonesia: Perspektif Antropologi. Linea Pustaka. Depok

https://desawisatabejiharjo.net/ada-apa-dengan-dewa-bejo-goa-pindul/, diakses tanggal 9 Januari 2020

https://desawisatabejiharjo.net/sejarah/, diakses tanggal 9 Januari 2020

http://www.berdesa.com/beda-desa-membangun-dan-membangun-desa/, diakses tanggal 9 Januari 2020.

https://www.merdeka.com/uang/data-bps-indonesia-miliki-1734-desa-wisata.html, diakses tanggal 9 Januari 2020 
https://angklungudjo.com/, diakses tanggal 9 Januari 2020

Kamarudin, K.H., (2013). Local Stakeholders Participation in Developing Sustainable Community Based Rural Tourism (CBRT): The Case of Three Villages in The East Coast of Malaysia. International Conference on Tourism Development, pp. $33-40$.

Long, P. and B. Lane, (2000), Rural Tourism Development in Trends in Recreation. Leisure, and Tourism, edited by W.C. Gartner and D.W. Lime, CABI:London

Musthofa, Budiman Mahmud. Pengembangan Budaya Menuju Kesejabteraan Budaya : Pelajaran Dari Pengembangan Masyarakat Di Saung Angklung Udjo, Bandung, Jawa Barat. Sosio Informa, [S.1.], v. 4, n. 3, jan. 2019. ISSN 2502-7913. Available at: <https://ejournal.kemsos.go.id/index.php/Sosioinforma/article/view/1600/875>. Date accessed: 08 mar. 2019. doi:https://doi.org/10.33007/inf.v4i3.1600.

Pitana, I Gde \& Putu G. Gayartri. (2005). Sosiologi Pariwisata. Penerbit Andi. Yogyakarta.

Ritchie, J. R. B., \& Crouch, G. (2003). The competitive destination: A sustainable tourism perspective. Cambridge, MA: CABI Publishing.

Sunaryo, Bambang. (2013). Kebijakan Pembangunan Destinasi Pariwisata Konsep dan Aplikasinya di Indonesia. Yogyakarta : Gava Media.

Sztompka, Piötr. (2011). Sosiologi Perubahan Sosial. Jakarta: Prenada Media. Cet ke 6

Tosun, C., (2000). Limits to Community Participation in the Tourism Development Process in Developing Countries, Tourism Management, 21, pp. 613-633, 2000.

UU No 6 Tahun 2014 tentang Desa.

UU No 10 tahun 2009 tentang Kepariwisataan.

Woodside, A. (2010). Brand-consumer storytelling theory and research: Introduction to a psychology \& marketing special issue. Psychology \& Marketing, 27(6), 531-540.

II | SGSIOGLLBAL : Jurnal Pemikiran dan Penelitian Sasiologi, Vol. 4, No. I, Desember 2019 